NBER WORKING PAPER SERIES

\title{
INSTITUTIONS AND GEOGRAPHY: \\ COMMENT ON ACEMOGLU, JOHNSON AND ROBINSON (2000)
}

\author{
John W. McArthur \\ Jeffrey D. Sachs \\ Working Paper 8114 \\ http://www.nber.org/papers/w8114 \\ NATIONAL BUREAU OF ECONOMIC RESEARCH \\ 1050 Massachusetts Avenue \\ Cambridge, MA 02138 \\ February 2001
}

We thank Bryan Graham for his insightful thoughts in a conversation regarding the ideas in this paper. The views expressed herein are those of the authors and not necessarily those of the National Bureau of Economic Research.

(C) 2001 by John W. McArthur and Jeffrey D. Sachs. All rights reserved. Short sections of text, not to exceed two paragraphs, may be quoted without explicit permission provided that full credit, including (C) notice, is given to the source. 
Institutions and Geography: Comment on Acemoglu, Johnson and Robinson (2000)

John W. McArthur and Jeffrey D. Sachs

NBER Working Paper No. 8114

February 2001

JEL No. O11, P16, P51, R11

\section{ABSTRACT}

This paper responds to findings by Acemoglu, Johnson and Robinson (2000) that suggest weak institutions, but not physical geography and correlates like disease burden, explain current variation in levels of economic development across former colonies. Using similar data and expanding the sample of countries analyzed, our regression analysis shows that both institutions and geographically-related variables such as malaria incidence or life expectancy at birth are strongly linked to gross national product per capita. We argue that the evidence presented in Acemoglu, Johnson and Robinson is likely limited by the inherently small sample of ex-colonies and the limited geographic dispersion of those countries.

John W. McArthur

Center for International Development

Harvard University

79 JFK Street

Cambridge, MA 02138

john_mcarthur@harvard.edu
Jeffrey D. Sachs

Center for International Development

Harvard University

79 JFK Street

Cambridge, MA 02138

and NBER

jeffrey_sachs@harvard.edu 


\section{Institutions and Geography: Comment on Acemoglu, Johnson, and Robinson (2000)}

Economists are increasingly aware of the deep links between physical geography and global patterns of economic development. Hall and Jones (1999), Gallup, Sachs, and Mellinger (1999), Engerman and Sokoloff (1997), Bloom and Sachs (1998), Masters and McMillan (2000), Sachs (2000), Masters and Wiebe (2000), and Acemoglu, Johnson, and Robinson (hereafter AJR, 2000), among others, all point out the strong correlation of geographical variables and cross-country levels of per capita income. Hall and Jones, for example, note that in a cross-section of countries, per capita income is positively correlated with the absolute value of latitude. Gallup, Sachs, and Mellinger stress the lower levels of Gross National Product (GNP) per capita in the tropics, arguing that human health and agricultural productivity are adversely impacted by tropical climate. Masters and McMillan similarly stress the positive effects of winter frost on agricultural productivity, and thereby on overall economic development. Meanwhile AJR argue that certain environments characterized by a heavy burden of infectious disease for would-be European settlers in the early $19^{\text {th }}$ century were exploited by predatory states rather than nurtured by the rule of law, and thereby failed to achieve sustained economic growth.

These strong links are vividly demonstrated by the following figures. Figure 1 shows a scatter plot of $\ln ($ GNP per capita in 1995), hereafter LGNP95, versus the absolute latitude of a central point of each country. The high-latitude countries are clearly much richer than the low-latitude (or tropical) countries. Figure 2 shows a related scatter plot linking LGNP95 and the mean annual temperature - which is itself related to latitude, of course, but contributes directly to disease ecology and agricultural productivity. Figure 3 shows a scatter plot linking LGNP95 to early $19^{\text {th }}$ century mortality rates across a sample of mainly ex-colonies, using a new data set assembled by AJR. Once again, we see that high mortality regions at the start of the $19^{\text {th }}$ century before the eras of modern economic growth and public health interventions - are regions of low economic development at the end of the $20^{\text {th }}$ century. This strongly suggests a link from disease ecology (mainly malaria) to long-term economic development. 
At least three basic models of geography-development interactions have been suggested by the recent papers, as shown in Figure 4. Figure 4a posits that geography affects income per capita mainly through the channel of institutions. Hall and Jones, for example, suggest that high-latitude countries were mainly settled by Europeans, who carried European traditions of rule of law and private property rights with them. The correlation of latitude and development, therefore, is mediated by institutions, particularly European institutions. AJR are of the same view, arguing that regions of high disease burden for European settlers in the early $19^{\text {th }}$ century eventually fell under exploitative colonial rule, rather than the rule of law. Such linkages via institutions might be modified as in Figure $4 \mathrm{~b}$, where climate (or disease ecology) affects technology (defined broadly to include the technologies of human health and agricultural production), technology affects institutions (such as slave versus free labor, or predatory versus rule-of-law states), and institutions ultimately determine GNP and economic growth. This is the model of Engerman and Sokoloff, who argue that tropical climates in the Americas led to plantation-style agriculture built upon coerced labor (especially slavery), which in turn suppressed the processes of market-oriented economic growth and development.

Figure $4 \mathrm{c}$ posits that geography affects economic development both through institutions (perhaps via technology) as well as directly through effects on productivity. This is the position of Gallup, Sachs, and Mellinger; Bloom and Sachs; Masters and McMillan; Masters and Wiebe; and Sachs, among others. Geography has many effects that work through channels other than economic and political institutions - such as effects on health, population growth, and food productivity. In this paper we focus on the links through public health. Tropical climates are burdened by many infectious diseases, such as malaria, which have much lower incidence and prevalence (if any) in temperate ecozones and which are much easier to control in the temperate zones (Sachs, 2000). Tropical climates also face special problems of agricultural management, and are characterized by lower average food output per unit input. In addition to these direct effects, the indirect effects of unfavorable geography may indeed be amplified by a tendency towards more predatory or exploitative government. Gallup, Sachs, and 
Mellinger illustrate why a more remote region, with less mobile factors of production, may face higher predatory taxation by a tax-maximizing sovereign.

Figure $4 \mathrm{~d}$ adds a specific pathway to $4 \mathrm{c}$. Climate again matters directly by affecting technology and institutions, but the effects may be amplified over time by the feedback of market size on further technological innovation. If tropical climates lower income, and if lower income in turn reduces technological innovation, then the initial adverse effects will be amplified over time through the dynamics of endogenous growth. As is well known, endogenous growth can easily produce a system of inter-linked economies in which the "rich get richer," as innovation increases market size which in turn supports an expanded rate of innovation.

This note picks up these themes as a response to the recent paper of AJR, who examine the importance of institutions and physical geography in determining the level of national income per capita in a cross-section of countries for the year 1995. ${ }^{1}$ They use a measure of expropriation risk (EXPROP) as the summary variable for institutional quality, and regress the level of GNP per capita on EXPROP. They note that EXPROP is likely to be endogenous. For example, high-income countries might better be able to protect property rights than poor countries, so causality would run from income to property, rather than the other way around. In a very useful and creative contribution, they produce and utilize a measure of mortality rates from the early $19^{\text {th }}$ century (hereafter LMORT) as an instrument for EXPROP. They then report IV regressions in which EXPROP, instrumented with LMORT, is a significant explanatory variable for GNP per capita, while claiming that other geographically-related variables apparently are not helpful in explaining GNP per capita. They conclude that institutions, rather than physical geography (and correlates such as disease burden), explain the cross-country patterns of per capita GNP in 1995, along the lines of Figure 4a or 4b.

\footnotetext{
${ }^{1}$ Although the AJR calculations are based on the 1999 World Development Indicators' figures for Gross Domestic Product per capita (PPP) in 1995, we use 1995 GNP per capita (PPP) from the 1997 World Development Indicators since this allows us to test a larger sample of countries. To check the robustness of our results, we ran parallel regressions using AJR's 1999 WDI GDP series and also the revised 1995 GDP series contained in the $2000 \mathrm{WDI}$. The test results are slightly weaker for the health variables with the 1999 WDI GDP series and slightly stronger with the 2000 WDI GDP series, but our basic conclusions remain unchanged. Detailed regression results are available from the authors.
} 
We review the evidence in AJR, and examine slightly different specifications as well. Our conclusion is different. The data strongly suggest that both institutions and geographically-related variables (such as malaria incidence or other health indicators) play a role in determining GNP per capita. We want to stress at the outset that the bivariate or trivariate regressions with relatively small samples in the AJR paper and in this paper are no doubt vast oversimplifications, and we certainly do not want to leave the impression that such over-simplified models are adequate explanations of cross-country income. Nonetheless, while such simple specifications cannot do justice to the full range of potential channels affecting development, both institutions and geography-specific health variables seem to play an important role, contrary to the claims in AJR.

We should also note how implausible the pathways are in Figure $4 \mathrm{a}$ and $4 \mathrm{~b}$ compared to Figures $4 \mathrm{c}$ and $4 \mathrm{~d}$. If, as AJR suggest, physical geography is powerful enough to determine social and political institutions, it is hard to see how it could affect those institutions without having direct effects on the production function itself. For example, if a disease environment associated with high mortality rates in the early $19^{\text {th }}$ century led European powers to develop predatory political institutions rather than developmental (or rule-of-law) institutions, it seems far-fetched to argue that the disease burden itself played no adverse role in the process of economic development. It is much more likely that the high disease burden has manifold direct effects, through worker stamina and productivity, longevity, household fertility and human capital accumulation, among other channels.

\section{Basic Regressions}

The dependent variable is the natural log of real GNP per capita at purchasing power parity in 1995 US dollars, LGNP95, as taken from the World Bank's 1997 World Development Indicators. The proxy for market institutions, EXPROP, measures the risk of confiscation and forced nationalization of property. Like AJR, we adopt this measure from Political Risk Services and calculate the average value for each country over the period 1985-95. However, unlike AJR, we allocate a value of EXPROP not just to 
former colonies but to all 118 economies assessed by Political Risk Services. Countries with higher values of EXPROP are those where expropriation of private foreign investment is a less likely event. This broader sample is important. Most of AJR's observations are for tropical and sub-tropical environments, which reduces the geographical variation of the observations. Our extended sample includes many more temperate-zone countries for comparison with tropical economies. We also report regressions using AJR's more restricted sample, with similar results to the broader sample in most cases.

We seek to examine whether other geographically-related variables, such as malaria prevalence or health indicators, are also significant in an instrumental-variables regression of LGNP95 on EXPROP. Thus, we examine the cross-section regression

\section{(1) LGNP95 $=\mathrm{a}+\mathrm{b}$ EXPROP $+\mathrm{cX}+\mathrm{e}$}

Our three candidates for $\mathrm{X}$ include:

MALFAL94 The proportion of a country's population at risk of falciparum malaria transmission in 1994, taken from Gallup, Sachs and Mellinger; ${ }^{2}$

LEB95 Life expectancy at birth in 1995, taken from United Nations (1996), and; ${ }^{3}$

IMR95 Infant mortality rate (deaths per 1,000 live births) in 1995, also taken from United Nations (1996).

The variable e is the error term. We are interested in health as a direct input to income levels, recognizing that cross-country differences in health status are importantly affected by physical geography (mainly because of disease ecology in tropical versus temperate

\footnotetext{
${ }^{2}$ Note that our MALFAL94 variable is slightly different from that used in AJR, but the two have a correlation coefficient of 0.96 .

${ }^{3}$ We also tested LEB95 and IMR95 in natural log form but found this to have a negligible effect on our results.
} 
ecozones). Of course, these variables may also be determined by income levels, so the $\mathrm{X}$ variables must be instrumented.

Instrumental variables must be correlated with the Xs but uncorrelated with the error term e. Our candidates for valid instruments include the following:

LMORT The natural $\log$ of adult mortality rates in the early $19^{\text {th }}$ century, as originally developed by Curtin (1989, 1998) and others, and collected by AJR; ${ }^{4}$

MEANTEMP 1987 mean annual temperature in degrees Celsius (which is correlated with disease ecology and hence the burden of disease), taken from Gallup, Sachs and Mellinger;

LT100KM Proportion of land area within $100 \mathrm{~km}$ of the sea coast, taken from Gallup, Sachs and Mellinger;

LATABS Absolute value of latitude, from the La Porta et al. (1999) data set;

LENERG Hydrocarbon production per capita, where hydrocarbons include oil and gas expressed in BTUs, as measured by the International Energy Agency. The variable is specified as $\ln (1+$ hydrocarbons per capita), as previously reported in Gallup, Sachs and Mellinger;

ELWARDUM Dummy variable $=1$ if a war during $1960 \mathrm{~s}$ to $1980 \mathrm{~s},=0$ otherwise, as calculated from the Easterly and Levine (1997) data set; and

STATE Period of national independence. $=0$ if independence before 1914;

\footnotetext{
${ }^{4}$ Specifically, our LMORT variable is based on AJR's "5th Mortality Estimate" in their Appendix Table A2.
} 
1 if independence between 1914 and 1945; 2 if independence between 1945 and 1989; and 3 if after 1989, as reported in CIA (1996).

The second through fourth variables on the IV list are clearly exogenous. The last three variables on the IV list are arguably endogenous to some extent, but their correlation with the error term e is likely to be small. ${ }^{5}$

Note that the geography variables are likely to be correlated both with the health measures (MALFAL94, IMR95, LEB95) and with EXPROP. The amount of a country's land near a sea coast (LT100KM), for example, changes diet (including availability of salt, iron, proteins, and other nutrients), disease ecology and technologies for controlling disease vectors such as mosquitoes. Coastal proximity may also affect the incentive of the state to tax production because of its effects on the mobility of factors of production (see Gallup and Sachs, 1998).

\section{Regression Results}

The key variables LGNP95, EXPROP, and the Xs are available for 118 countries. LMORT is available for 68 countries. When we include LMORT in the IV list, we drastically cut the sample of countries. Thus, we estimate the core equation with the smaller and larger samples while excluding the LMORT instrument in order better to compare the effects of the instruments to the effects of the sample size. In all cases, we try the three alternative measures of $\mathrm{X}$.

Regressions 1 through 3 in Table 1 report OLS regressions for the three respective $\mathrm{X}$ variables. The sample for each regression includes at least 116 countries. In all three regressions, both EXPROP and the health variable $\mathrm{X}$ are highly significant. (If they are included together, only IMR95 is significant.) In regression 1 , the coefficient of 0.35 on

\footnotetext{
${ }^{5}$ Even though the specification used in equation (1) is highly simplified, we note that LENERG has a larger correlation with the error term than the other instruments and can arguably be used as an independent righthand-side variable. In results not reported for the sake of conserving space, we tested specifications with such a structure but our findings were essentially unchanged in terms of the significance of the health variables, even when the energy variable was a significant right-hand-side variable. These unreported regressions are available from the authors upon request.
} 
EXPROP suggests that a one standard deviation (SD) increase in the expropriation index away from the mean level is linked to a $89 \%$ higher GNP per capita. ${ }^{6}$ Meanwhile, a one SD increase in a country's malaria index is linked to a $39 \%$ lower GNP per capita. ${ }^{7}$ In regression 2, we see a slight drop in the coefficient on EXPROP and again find the health variable to be significant. An extra year of life expectancy at birth for a country is linked to a 5\% higher GNP per capita. Stated otherwise, a one SD increase in LEB95 from the mean level is associated with an $80 \%$ increase in GNP per capita. ${ }^{8}$ Looking at regression 3 , we see that one extra death per 1,000 live births is linked to a 2 percent lower LGNP95. In terms of the distribution of IMR95, a one SD increase in deaths per 1,000 live births is linked to a $54 \%$ decrease in per capita GNP. ${ }^{9}$

Regressions 4 to 6 report the same basic OLS regressions, this time limiting the sample to the approximately 62 (mainly) ex-colonies examined in the AJR paper. ${ }^{10}$ The results here are almost identical to those in regressions 1 through 3. However, as AJR and others have pointed out, there is likely some endogeneity in the parsimonious specifications of regressions 1 through 6 . We address this through IV regressions in equations 7 to 9 by using the three instruments most likely to be exogenous, MEANTEMP, LT100KM and LATABS. Here we again see broadly consistent coefficients on the Xs, with reduced but still significant t-statistics. Even when including the instruments, we see in this "full" sample of ex-colonies plus other countries that geographically-related health variables are highly linked to LGNP95.

To help distinguish between general effects of the RHS variables and effects determined by sample composition, regressions 10 to 12 mimic the specification in equations 7 to 9 , but here we limit the sample to (mainly) ex-colonies, most of which are

\footnotetext{
${ }^{6}$ The mean value of EXPROP across the sample is 7.02 and its SD is 1.82 . Multiplying the SD by the coefficient of 0.35 and taking the exponential gives us: $\exp (1.82 * 0.35)=1.89$.

${ }^{7}$ The mean value of MALFAL94 across the sample is 0.29 and its SD is 0.41 . Multiplying the SD by the coefficient of -1.2 and taking the exponential gives us: $\exp \left(0.41^{*}-1.2\right)=0.61$.

${ }^{8}$ The mean value of LEB95 for the sample of countries with values for EXPROP is 65.06 and the SD is 11.77. Multiplying the SD by the coefficient of 0.05 and taking the exponential gives us: $\exp \left(11.77^{*} 0.05\right)$ $=1.80$.

${ }^{9}$ The mean value of IMR95 for the sample of countries with values for EXPROP is 46.12 and the SD is 38.74. Multiplying the SD by the coefficient of -0.02 and taking the exponential gives us: $\exp (38.74 *$ $-0.02)=0.46$.

${ }^{10}$ AJR include France and the UK in their sample of ex-colonies. We do the same here.
} 
located in tropical or semi-tropical climatic regions. When the sample is limited as such, we see that the coefficients on EXPROP roughly double to the 0.6 range while the coefficients on MALFAL94 and LEB95 are no longer significant at 5\% levels. The coefficient on IMR95 decreases by one half to -0.01 and its t-statistic decreases substantially, but it still remains significant at $10 \%$ levels.

The result seems to provide evidence that, although geographically-related health variables are important across regions, they are less important within the geographicallylimited region (mainly tropical) that contains most ex-colonies. We note that the Rsquared values in regression 10 through 11 have dropped about 15\% from regressions 4 through 6. This on its own, of course, does not imply anything directly, but it does suggest that equations 10 through 12 are somewhat weaker for explaining GNP variance when looking only at ex-colonies. Nevertheless, even within the set of ex-colonies, infant mortality rates still appear to be importantly linked to LGNP95. An alternatively plausible interpretation would suggest that the MALFAL94 and LEB95 variables lose significance due to the sheer numerical limitations of an ex-colony sample with only 60 observations.

In regressions 13 through 15, we test the AJR argument more directly by including their LMORT instrumental variable. Again, this decreases the sample size significantly, but also tests more explicitly the findings posited by AJR in their Table 7 . As in regressions 10 and 11, we find MALFAL94 and LEB95 to be insignificant. In regression 15, however, we again find IMR95 to be our most robust variable, here significant at $5 \%$ levels. The inclusion of the mortality instrument does not seem to weaken the significance of the geographically-linked infant mortality variable.

Regressions 16 through 18 add LENERG, ELWARDUM, and STATE to the IV list. Here the sample is still limited at approximately 60 countries, but the R-squared measure of fit has increased and the $\mathrm{X}$ variables all return to being highly significant, with coefficients very similar to those in regressions 1 through 9. Interestingly the coefficient on EXPROP is much greater than the relevant values in equations 1 through 9 and it remains highly significant. As mentioned above, the three instruments we add here 
are arguably endogenous, but they have a low degree of correlation with the error term in equation (1), so our results supporting the role of the $\mathrm{X}$ variables should still hold.

In equations 19 through 21 we repeat the previous three regressions but this time exclude the LMORT variable so that we can test the full set of instruments on a sample of more than 100 countries. Again, our main results are unchanged, with the coefficients on EXPROP, MALFAL94, LEB95 and IMR95 remaining highly significant and of essentially the same magnitude as in equations 1 through 9. This evidence further consolidates the view that AJR's argument against physical geography is limited by its small sample and small range of geographic variation.

\section{Conclusions}

Although it is difficult to extract ironclad conclusions from the highly simplified regressions above, the analysis indicates that both institutions and geographically-related variables play a significant role in determining GNP per capita. The pathways from geography to development seem to be characterized by Figures $4 \mathrm{c}$ and $4 \mathrm{~d}$, rather than Figures $4 \mathrm{a}$ and $4 \mathrm{~b}$. We find that, despite their contribution in identifying the LMORT instrument, AJR's argument that geography plays a limited role in development is likely due to the inherently small sample of ex-colonies and to the limited geographic dispersion of those countries. Even within that small sample, most regression results point squarely to direct effects of geographically-linked health variables on development, controlling for the quality of governance. Since most colonies were located within tropical zones, it is likely that the lesser variance in geography, climate and disease ecology across colonies is responsible for the decreased significance of health variables when they are included in the ex-colony regressions. This problem is exacerbated by the more standard small sample problems that might be affecting the same regressions. Indeed, when we test our specification with 3 exogenous instruments and a sample of more than 100 countries in regressions 7 through 9, both institutions and geographical variables are significantly linked to an increase in economic development. Likewise, when we test our specification with a slate of six instruments and more than 100 countries in regressions 19 through 21, both the institutional and geographic variables are highly significant. 
What is perhaps most notable from our regressions is the relative magnitude of effects implied by the EXPROP and X coefficients respectively. A one SD increase in EXPROP is linked to a roughly $80-90 \%$ higher GNP per capita, indicating that institutions play a considerable role. Meanwhile a one SD increase in infant mortality rates, our most robust geographically-based health measure, is linked to a roughly $50 \%$ decrease in GNP per capita. While the simplistic specification in equation (1) implies one cannot interpret these regression coefficients too literally, the findings do strongly suggest that both institutions and geographically-related variables play a major role in affecting countries' levels of wealth. 
Figure 1. Scatter plot of LGNP95 versus absolute latitude, LATABS, for 150 countries.

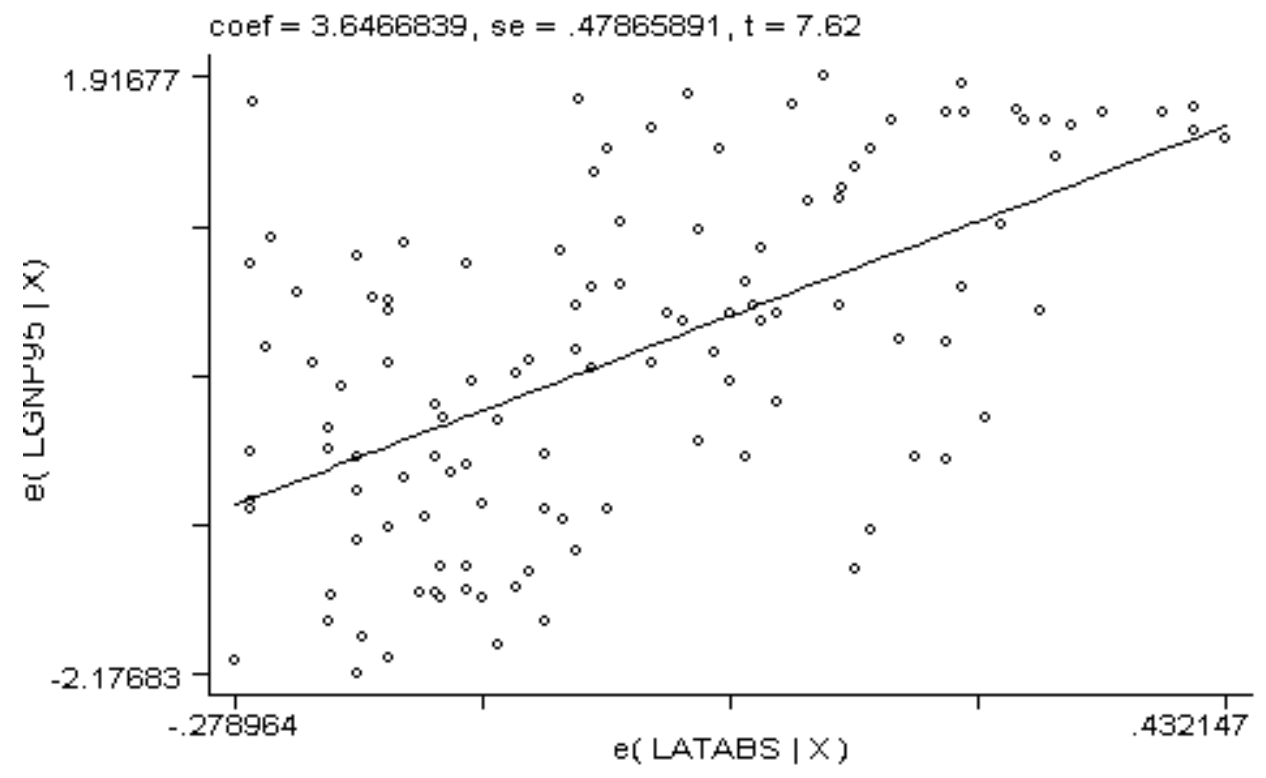

Figure 2. Scatter plot of LGNP95 versus mean temperature, MEANTEMP, for 123 countries.

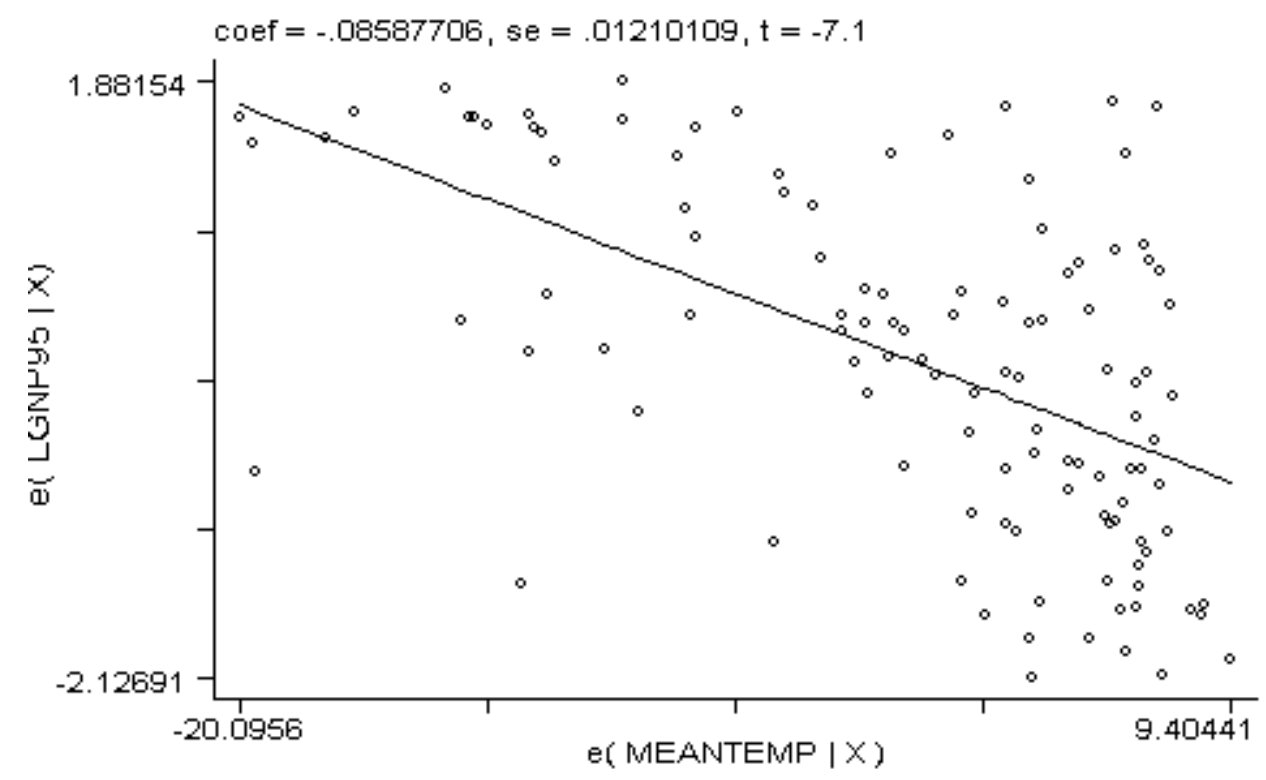


Figure 3. Scatter plot of LGNP95 versus $19^{\text {th }}$ century mortality variable, LMORT, for 68 countries (mainly ex-colonies).

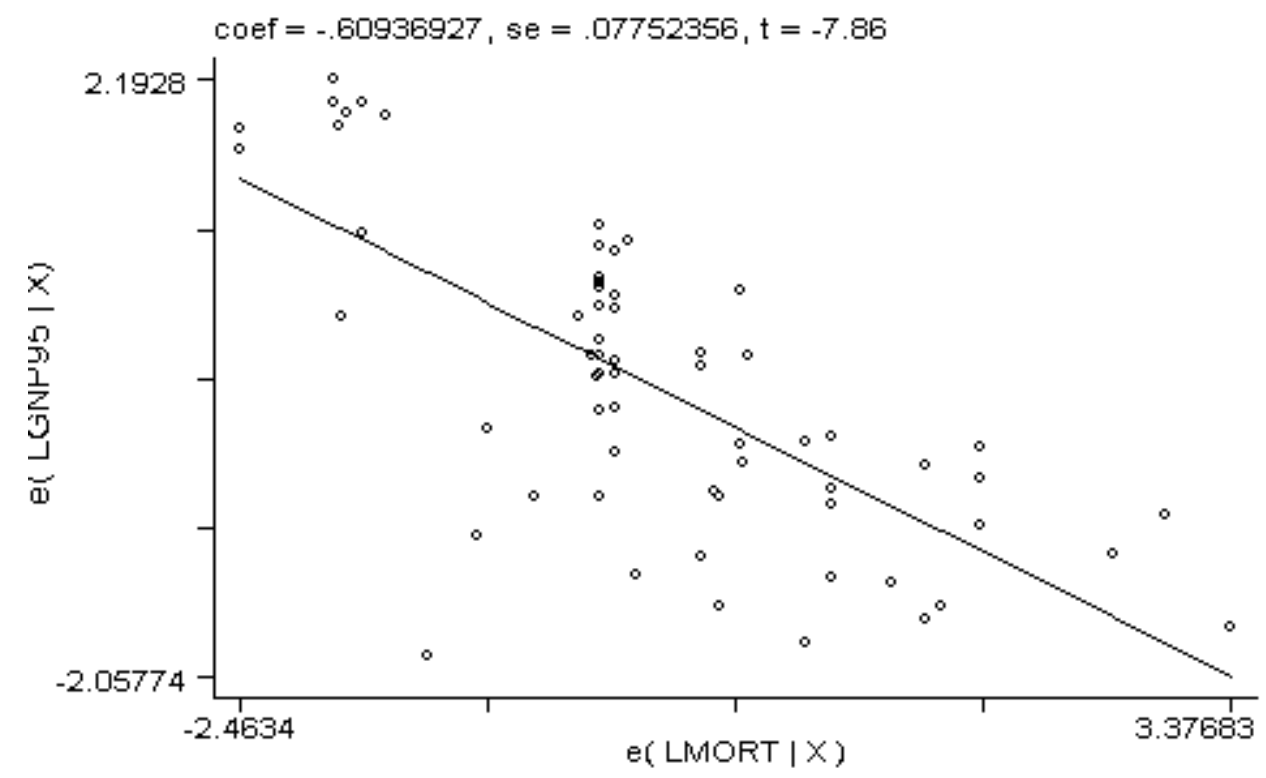


Figure 4. Hypothesized Linkages of Geography and Economic Development

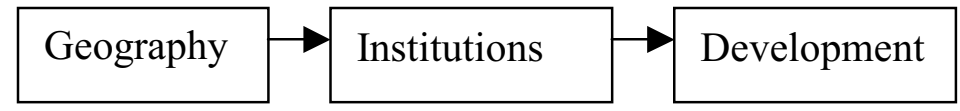

(Example: AJR. High disease environment leads to predatory state institutions, which impede long-term development)

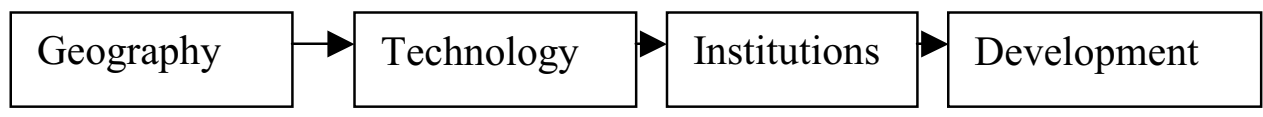

(Example: Engerman and Sokoloff. Tropical ecozones lead to plantation agriculture, which promote the use of slavery, which impede economic development)

(c)

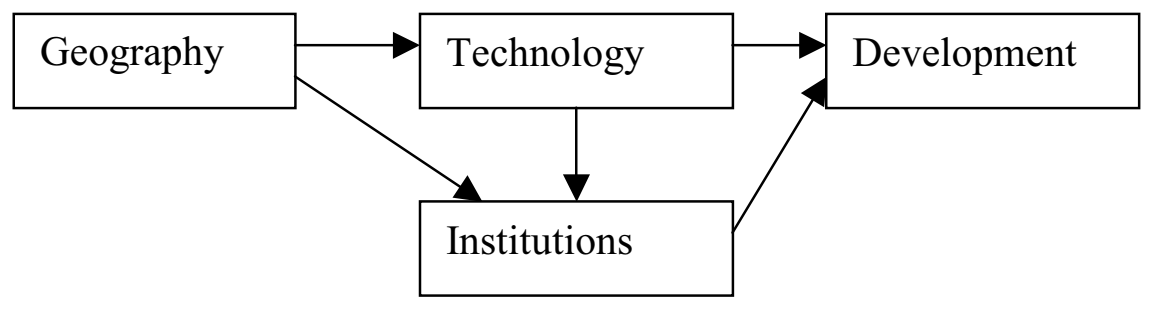

(Example: Gallup, Sachs, and Mellinger. Adverse geography diminishes agriculture productivity and health, thereby directly impeding development. Adverse geography also promotes state predation, leading to predatory institutions and poor development)

(d)

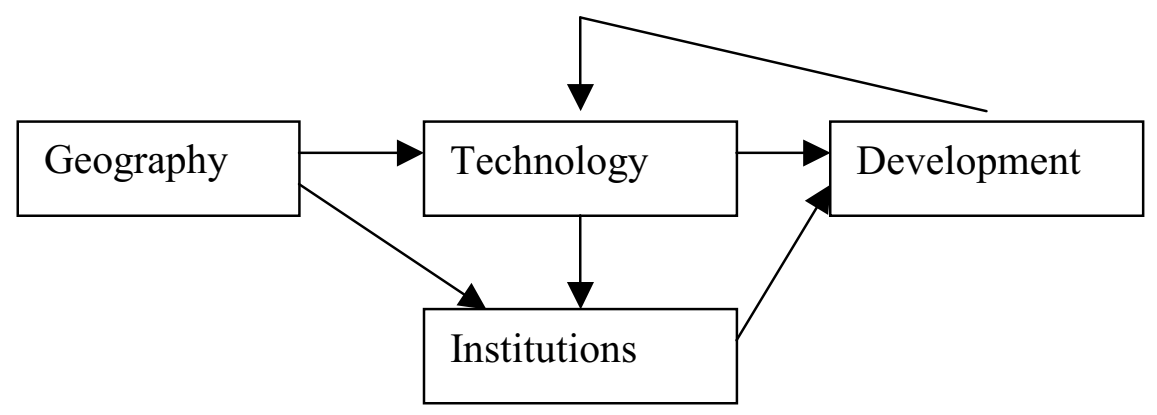

(Example: Sachs, 2000. Adverse geography has direct effects on production, and indirect effects via institutions, which both lead low levels of development. In turn, low levels of development result in low levels of innovation and slow technological change. The pace of endogenous growth is thereby reduced). 
Table 1. Regression Results

LGNP95 as dependent variable throughout

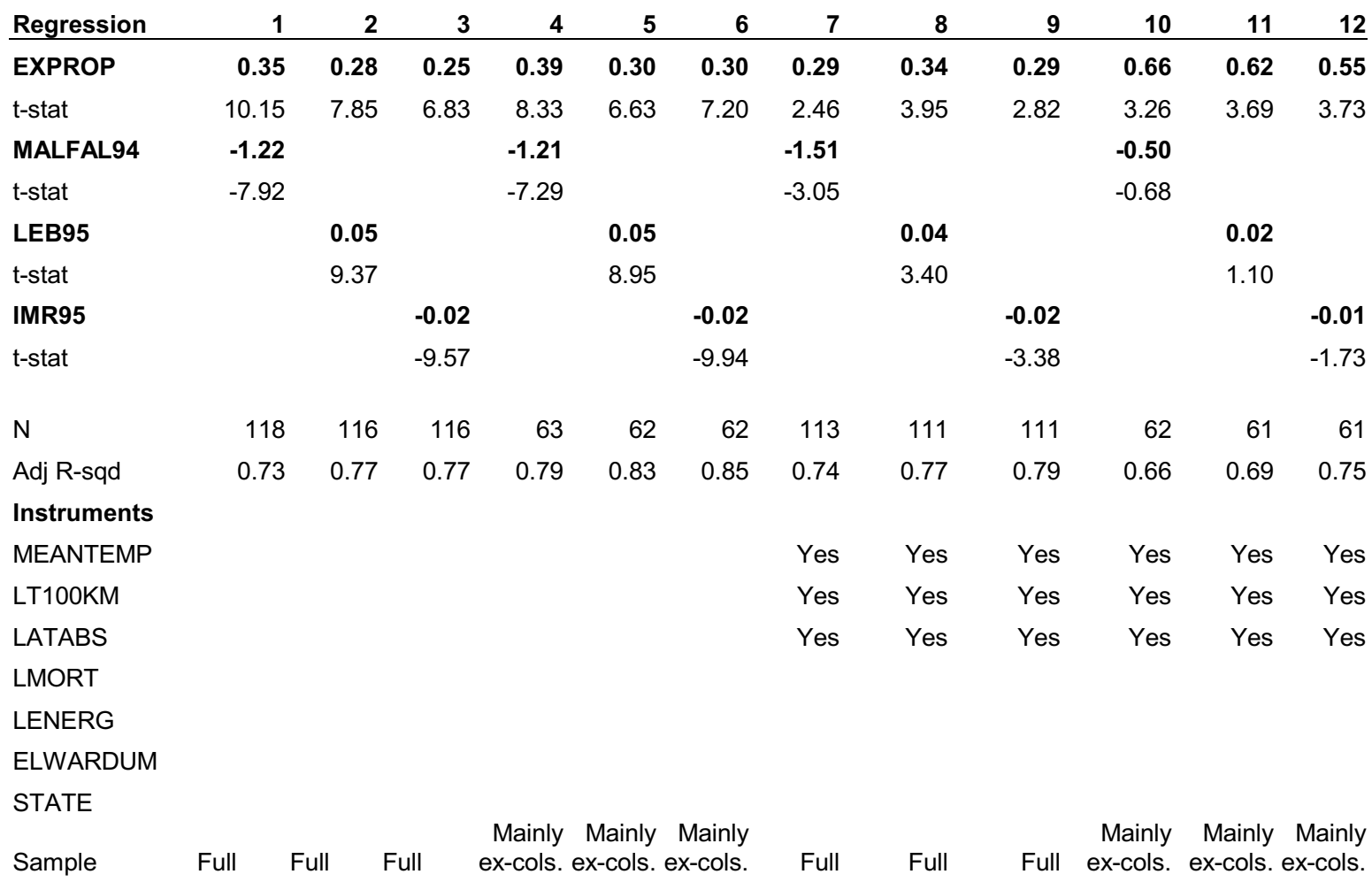

LGNP95 as dependent variable throughout

\begin{tabular}{|c|c|c|c|c|c|c|c|c|c|}
\hline Regression & 13 & 14 & 15 & 16 & 17 & 18 & 19 & 20 & 21 \\
\hline EXPROP & 0.62 & 0.60 & 0.54 & 0.49 & 0.42 & 0.39 & 0.39 & 0.34 & 0.28 \\
\hline t-stat & 3.50 & 3.73 & 3.86 & 6.14 & 5.12 & 5.13 & 6.48 & 5.89 & 4.49 \\
\hline MALFAL94 & -0.72 & & & -1.21 & & & -1.22 & & \\
\hline t-stat & -1.24 & & & -4.81 & & & -4.72 & & \\
\hline LEB95 & & 0.03 & & & 0.05 & & & 0.05 & \\
\hline t-stat & & 1.43 & & & 5.20 & & & 5.85 & \\
\hline IMR95 & & & -0.01 & & & -0.02 & & & -0.02 \\
\hline t-stat & & & -2.13 & & & -5.84 & & & -6.32 \\
\hline$N$ & 62 & 61 & 61 & 62 & 61 & 61 & 105 & 103 & 103 \\
\hline Adj R-sqd & 0.71 & 0.73 & 0.76 & 0.78 & 0.80 & 0.83 & 0.80 & 0.83 & 0.85 \\
\hline \multicolumn{10}{|l|}{ Instruments } \\
\hline MEANTEMP & Yes & Yes & Yes & Yes & Yes & Yes & Yes & Yes & Yes \\
\hline LT100KM & Yes & Yes & Yes & Yes & Yes & Yes & Yes & Yes & Yes \\
\hline LATABS & Yes & Yes & Yes & Yes & Yes & Yes & Yes & Yes & Yes \\
\hline LMORT & Yes & Yes & Yes & Yes & Yes & Yes & & & \\
\hline LENERG & & & & Yes & Yes & Yes & Yes & Yes & Yes \\
\hline STATE & & & & Yes & Yes & Yes & Yes & Yes & Yes \\
\hline ELWARDUM & & & & Yes & Yes & Yes & Yes & Yes & Yes \\
\hline Sample & $\begin{array}{l}\text { Mainly } \\
\text { ex-cols. }\end{array}$ & $\begin{array}{l}\text { Mainly } \\
\text { x-cols }\end{array}$ & $\begin{array}{l}\text { Mainly } \\
\text { ex-cols e }\end{array}$ & $\begin{array}{l}\text { Mainly } \\
\text { x-cols. e }\end{array}$ & $\begin{array}{l}\text { Mainly } \\
\text { x-cols. e }\end{array}$ & $\begin{array}{l}\text { Mainly } \\
\text { ex-cols. }\end{array}$ & Full & Full & Full \\
\hline
\end{tabular}


APPENDIX: LIST OF DATA

\begin{tabular}{|c|c|c|c|c|c|c|c|c|c|c|c|c|c|c|}
\hline Country & GNP95 & LGNP95 & PROPN & ALFAL94 & LEB95 & IMR95 & LMORT & MEANTEMP & LT100KM & LATABS & LENERG & MORT5TH & ELWARDUM & STATE \\
\hline Afghanistan & 600 & 6.39693 & & 0.00438 & 45.48 & 152 & & 16.1 & 0 & 0.366667 & -6.55297 & & 1 & 1 \\
\hline Albania & 1210 & 7.09838 & 6.96 & 0 & 72.75 & 30 & & 15.7 & 0.852781 & 0.455556 & -4.94275 & & 0 & 0 \\
\hline Algeria & 5300 & 8.57546 & 6.55 & 0 & 68.89 & 43.8 & 4.35927 & 19.3 & 0.047186 & 0.311111 & -1.74396 & 78.2 & 1 & 2 \\
\hline Angola & 1310 & 7.17778 & 5.37 & 1 & 46.49 & 125 & 5.63479 & 22.94133 & 0.118758 & 0.136667 & -2.03993 & 280 & 1 & 2 \\
\hline Argentina & 8310 & 9.02521 & 6.5 & 0 & 72.89 & 21.8 & 4.26268 & 17.1 & 0.123089 & 0.377778 & -2.60781 & 71 & 1 & 0 \\
\hline Armenia & 2260 & 7.72312 & & 0 & 70.47 & 25.7 & & & 0 & 0.444444 & -6.90776 & & 1 & 3 \\
\hline Australia & 18940 & 9.84903 & 9.32 & 0 & 78.25 & 5.6 & 2.14593 & 20.9 & 0.198958 & 0.3 & -2.07886 & 8.55 & 0 & 0 \\
\hline Austria & 21250 & 9.96411 & 9.74 & 0 & 77.02 & 6.2 & & 6.6 & 0.007585 & 0.524445 & -4.22278 & & 0 & 1 \\
\hline Azerbaijan & 1460 & 7.28619 & & 0 & 69.86 & 36.3 & & & 0 & 0.447778 & -2.4983 & & & 3 \\
\hline Bangladesh & 1380 & 7.22984 & 5.18 & 0.158 & 58.13 & 78.8 & 4.26844 & 25.68621 & 0.401598 & 0.266667 & -5.80785 & 71.41 & 1 & 2 \\
\hline Belarus & 4220 & 8.34759 & & 0 & 67.98 & 22.5 & & & 0 & 0.588889 & -4.63512 & & & 3 \\
\hline Belgium & 21660 & 9.98322 & 9.69 & 0 & 77.21 & 7 & & 8.4 & 0.489252 & 0.561111 & -6.90776 & & 0 & 0 \\
\hline Benin & 1760 & 7.47307 & & 1 & 53.43 & 87.6 & & 26.8 & 0.108962 & 0.103333 & -5.86872 & & 0 & 2 \\
\hline Bolivia & 2540 & 7.83992 & 5.74 & 0.00528 & 61.39 & 65.6 & 4.26268 & 21.5 & 0 & 0.188889 & -3.73264 & 71 & 0 & 0 \\
\hline Bosnia and Herzegovina & 600 & 6.39693 & & 0 & 73.26 & 15.4 & & & 0.36765 & 0.488889 & -4.84793 & & & 3 \\
\hline Botswana & 5580 & 8.62694 & 7.74 & 0.39 & 47.39 & 58.5 & & 21.075 & 0 & 0.244444 & -6.90776 & & 0 & 2 \\
\hline Brazil & 5400 & 8.59415 & 7.9 & 0.1935 & 66.78 & 42.4 & 4.26268 & 23.7 & 0.092516 & 0.111111 & -4.45553 & 71 & 1 & 0 \\
\hline Bulgaria & 4480 & 8.40738 & 8.92 & 0 & 71.05 & 17.1 & & 10.7 & 0.273645 & 0.477778 & -6.90776 & & 0 & 0 \\
\hline Burkina Faso & 780 & 6.65929 & 4.5 & 1 & 44.39 & 98.8 & 5.63479 & 28.1 & 0 & 0.144444 & -6.90776 & 280 & 0 & 2 \\
\hline Burundi & 630 & 6.44572 & & 1 & 42.44 & 119 & & 23.39 & 0 & 0.036667 & -6.90776 & & 1 & 2 \\
\hline Cambodia & 660 & 6.49224 & & 0.896 & 53.36 & 103 & & 27.22083 & 0.224321 & 0.144445 & -6.90776 & & 1 & 2 \\
\hline Cameroon & 2110 & 7.65444 & 6.42 & 1 & 54.73 & 74.4 & 5.63479 & 24.43333 & 0.09824 & 0.066667 & -3.96009 & 280 & 1 & 2 \\
\hline Canada & 21130 & 9.95845 & 9.74 & 0 & 78.98 & 6 & 2.77882 & -0.2 & 0.021164 & 0.666667 & -1.12626 & 16.1 & 0 & 0 \\
\hline Central African Republic & 1070 & 6.97541 & & 1 & 44.86 & 97.9 & 5.63479 & 25.46486 & 0 & 0.077778 & -6.90776 & 280 & 0 & 2 \\
\hline Chad & 700 & 6.55108 & & 0.7 & 47.19 & 112 & 5.63479 & 27.97222 & 0 & 0.166667 & -6.90776 & 280 & 1 & 2 \\
\hline Chile & 9520 & 9.16115 & 7.82 & 0 & 74.94 & 12.8 & 4.26268 & 13.4 & 0.660182 & 0.333333 & -4.9162 & 71 & 1 & 0 \\
\hline China & 2920 & 7.97934 & 7.79 & 0.00552 & 69.83 & 41 & & 11.7 & 0.051712 & 0.388889 & -4.97279 & & 1 & 0 \\
\hline Colombia & 6130 & 8.72095 & 7.39 & 0.2499 & 70.43 & 30 & 4.26268 & 22.5 & 0.159722 & 0.044444 & -3.21597 & 71 & 1 & 0 \\
\hline Congo & 2050 & 7.6256 & 4.63 & 1 & 48.55 & 89.5 & 5.48064 & 24.75151 & 0.047893 & 0.011111 & -1.87785 & 240 & 0 & 2 \\
\hline Congo DR & 490 & 6.19441 & 3.66 & 1 & 50.79 & 90.2 & 5.48064 & 23.35455 & 0.003987 & 0 & -6.04556 & 240 & 1 & 2 \\
\hline Costa Rica & 5850 & 8.6742 & 6.97 & 0 & 76.03 & 12.1 & 4.35799 & 25.1 & 1 & 0.111111 & -6.90776 & 78.1 & 0 & 0 \\
\hline Cote d'Ivoire & 1580 & 7.36518 & 7 & 1 & 46.72 & 87.3 & 6.50429 & 26.0907 & 0.171056 & 0.088889 & -6.01953 & 668 & 0 & 2 \\
\hline Croatia & 4250 & 8.35467 & & 0 & 72.64 & 10.3 & & & 0.493505 & 0.501111 & -3.49658 & & & 3 \\
\hline Cuba & 1300 & 7.17012 & 7.02 & 0 & 75.66 & 9 & & 27.4 & 1 & 0.236667 & -5.04382 & & & 0 \\
\hline
\end{tabular}




\begin{tabular}{|c|c|c|c|}
\hline Czech Republic & 9770 & 9.18707 & 9.8 \\
\hline Denmark & 21230 & 9.96317 & 9.74 \\
\hline Dominican Republic & 3870 & 8.26101 & 6.25 \\
\hline Ecuador & 4220 & 8.34759 & 6.56 \\
\hline Egypt & 3820 & 8.24801 & 6.77 \\
\hline El Salvador & 2610 & 7.86711 & 5.01 \\
\hline Eritrea & 570 & 6.34564 & \\
\hline Estonia & 4220 & 8.34759 & \\
\hline Ethiopia & 450 & 6.10925 & 5.7 \\
\hline Finland & 17760 & 9.7847 & 9.74 \\
\hline France & 21030 & 9.95371 & 9.74 \\
\hline Gabon & 7430 & 8.91328 & 7.81 \\
\hline Gambia & 930 & 6.83518 & 8.27 \\
\hline Georgia & 1470 & 7.29302 & \\
\hline Germany & 20070 & 9.90698 & 9.91 \\
\hline Ghana & 1990 & 7.59589 & 6.32 \\
\hline Greece & 11710 & 9.3682 & 7.78 \\
\hline Guatemala & 3340 & 8.11373 & 5.12 \\
\hline Guinea & 1735 & 7.45876 & 6.55 \\
\hline Guinea Bissau & 790 & 6.67203 & 4.55 \\
\hline Haiti & 910 & 6.81344 & 3.77 \\
\hline Honduras & 1900 & 7.54961 & 5.33 \\
\hline Hong Kong & 22950 & 10.0411 & 8.13 \\
\hline Hungary & 6410 & 8.76561 & 9.01 \\
\hline India & 1400 & 7.24423 & 8.28 \\
\hline Indonesia & 3800 & 8.24276 & 7.53 \\
\hline Iran & 5350 & 8.58485 & 4.78 \\
\hline Iraq & 2000 & 7.6009 & 1.81 \\
\hline Ireland & 15680 & 9.66014 & 9.74 \\
\hline Israel & 16490 & 9.71051 & 8.59 \\
\hline Italy & 19870 & 9.89697 & 9.46 \\
\hline Jamaica & 3540 & 8.17188 & 7.04 \\
\hline Japan & 22110 & 10.0038 & 9.74 \\
\hline Jordan & 4060 & 8.30894 & 6.76 \\
\hline Kazakhstan & 3010 & 8.0097 & \\
\hline Kenya & 1380 & 7.22984 & 6.15 \\
\hline Korea & 11450 & 9.34575 & 8.71 \\
\hline Korea, DPR & 920 & 6.82437 & 4.53 \\
\hline
\end{tabular}

\begin{tabular}{|c|c|c|c|}
\hline 0 & 73.88 & 6.3 & \\
\hline 0 & 75.65 & 7.1 & \\
\hline 0 & 70.61 & 33.6 & 4.86753 \\
\hline 0.13725 & 69.52 & 45.6 & 4.26268 \\
\hline 0 & 66.27 & 50.5 & 4.21656 \\
\hline \multirow[t]{2}{*}{0} & 69.13 & 32 & 4.35799 \\
\hline & 50.81 & 91.4 & \\
\hline 0 & 68.68 & 19.1 & \\
\hline 0.75 & 43.32 & 116 & 3.2581 \\
\hline 0 & 76.83 & 5.6 & \\
\hline 0 & 78.12 & 6.4 & 3.0042 \\
\hline 1 & 52.42 & 87.3 & \\
\hline 1 & 47 & 122 & 7.29302 \\
\hline 0 & 72.73 & 19.5 & \\
\hline 0 & 77.21 & 5.2 & \\
\hline 1 & 60 & 65.8 & 6.50429 \\
\hline 0 & 78.11 & 7.9 & \\
\hline 0.012 & 64.04 & 46 & 4.26268 \\
\hline 1 & 46.5 & 124 & 6.18002 \\
\hline 1 & 44.95 & 130 & \\
\hline 1 & 53.75 & 67.7 & 4.86753 \\
\hline 0.0108 & 69.4 & 35 & 4.35799 \\
\hline 0 & & & 2.70136 \\
\hline 0 & 70.87 & 10.2 & \\
\hline 0.28107 & 62.59 & 72.3 & 3.88424 \\
\hline 0.42594 & 65.13 & 48.4 & 5.1358 \\
\hline 0.15232 & 69.22 & 35.3 & \\
\hline 0.00208 & 62.39 & 95.3 & \\
\hline 0 & 76.35 & 7.2 & \\
\hline 0 & 77.75 & 8.3 & \\
\hline 0 & 78.17 & 7 & \\
\hline 0 & 74.82 & 21.9 & 4.86753 \\
\hline 0 & 79.96 & 4.3 & \\
\hline 0 & 70.15 & 26.2 & \\
\hline 0 & 67.64 & 34.7 & \\
\hline 0.91 & 52.04 & 65.5 & 4.97673 \\
\hline 0 & 72.42 & 10 & \\
\hline 0 & 72.2 & 21.6 & \\
\hline
\end{tabular}

$\begin{array}{rrrr} & 0 & 0.549444 & -5.8308 \\ 6.8 & 1 & 0.622222 & -2.15466 \\ 25.6 & 1 & 0.211111 & -6.90776 \\ 19.1 & 0.368411 & 0.022222 & -2.5665 \\ 22.6 & 0.239163 & 0.3 & -3.13758 \\ 23.57101 & 1 & 0.15 & -6.90776 \\ & 0.547415 & 0.166667 & -6.90776 \\ & 0.745796 & 0.655556 & -6.90776 \\ & 0.021018 & 0.088889 & -6.90776 \\ 0.2 & 0.283328 & 0.711111 & -6.90776 \\ 11.2 & 0.329235 & 0.511111 & -5.30606 \\ 24.5 & 0.261791 & 0.011111 & -0.32126 \\ 25.66596 & 0.39977 & 0.147556 & -6.90776 \\ & 0.309005 & 0.466667 & -6.90776 \\ 7.2 & 0.186077 & 0.566667 & -4.53083 \\ 26.35758 & 0.192991 & 0.088889 & -6.44676 \\ 16.9 & 0.929971 & 0.433333 & -5.83934 \\ 21.7 & 0.425458 & 0.17 & -6.90776 \\ 24.43889 & 0.140641 & 0.122222 & -6.90776 \\ 26.49706 & 0.687065 & 0.133333 & -6.90776 \\ 26.58033 & 1 & 0.211111 & -6.90776 \\ 25.4 & 0.668602 & 0.166667 & -6.90776 \\ 22.6 & 1 & 0.246111 & -6.90776 \\ 9 & 0 & 0.522222 & -3.67142 \\ 25.9 & 0.156776 & 0.222222 & -5.69687 \\ 26.8 & 0.74576 & 0.055556 & -3.50915 \\ 23.30714 & 0.10122 & 0.355556 & -1.94002 \\ 22.60615 & 0.015001 & 0.366667 & -2.71532 \\ 9.2 & 0.913389 & 0.588889 & -3.54439 \\ 19.2 & 0.933205 & 0.347778 & -6.90776 \\ 13.4 & 0.777446 & 0.472222 & -4.0595 \\ 26.5 & 1 & 0.201667 & -6.90776 \\ 14.6 & 0.939948 & 0.4 & -6.27728 \\ 18.1 & 0.131246 & 0.344445 & -5.69161 \\ & 0 & 0.533333 & -2.84373 \\ 22.6 & 0.082504 & 0.011111 & -6.90776 \\ 13.1 & 0.891181 & 0.411111 & -6.90776 \\ 8.2 & 0.741983 & 0.444444 & -6.90776\end{array}$

\begin{tabular}{|c|c|}
\hline & \\
\hline 130 & 1 \\
\hline 71 & 0 \\
\hline 67.8 & 1 \\
\hline 78.1 & 1 \\
\hline & \\
\hline 26 & 1 \\
\hline & 0 \\
\hline 20.17 & 0 \\
\hline & 0 \\
\hline 1470 & 0 \\
\hline & 0 \\
\hline 668 & 1 \\
\hline & 0 \\
\hline 71 & 1 \\
\hline 483 & 0 \\
\hline & 1 \\
\hline 130 & 0 \\
\hline 78.1 & 1 \\
\hline 14.9 & 0 \\
\hline & 0 \\
\hline 48.63 & 1 \\
\hline 170 & 1 \\
\hline & \\
\hline & 0 \\
\hline & 1 \\
\hline & 0 \\
\hline 130 & 1 \\
\hline & 0 \\
\hline & 0 \\
\hline 145 & 1 \\
\hline & 1 \\
\hline
\end{tabular}




\begin{tabular}{|c|c|c|c|c|c|c|c|}
\hline Kuwait & 23790 & 10.077 & 7.08 & 0 & 75.92 & 12.3 & \\
\hline Kyrgyzstan & 1800 & 7.49554 & & 0 & 67.64 & 40.1 & \\
\hline Laos & 1190 & 7.08171 & & 0.863 & 53.23 & 93.3 & \\
\hline Latvia & 3370 & 8.12267 & & 0 & 68.42 & 18.1 & \\
\hline Lebanon & 5573 & 8.62569 & 5.16 & 0 & 69.92 & 29.2 & \\
\hline Lesotho & 1780 & 7.48437 & & 0 & 56.02 & 92.9 & \\
\hline Liberia & 770 & 6.64639 & 3.65 & 1 & 47.3 & 116 & \\
\hline Libya & 6510 & 8.78109 & 5.25 & 0 & 69.96 & 27.7 & \\
\hline Lithuania & 4120 & 8.32361 & & 0 & 69.89 & 20.5 & \\
\hline Macedonia & 880 & 6.77992 & & 0 & 73.06 & 23.3 & \\
\hline Madagascar & 640 & 6.46147 & 4.51 & 1 & 57.51 & 82.5 & 6.28421 \\
\hline Malawi & 750 & 6.62007 & 6.79 & 1 & 39.27 & 138 & \\
\hline Malaysia & 9020 & 9.1072 & 7.98 & 0.46662 & 72 & 11.4 & 2.87356 \\
\hline Mali & 550 & 6.30992 & 4 & 0.62 & 53.3 & 118 & 7.98616 \\
\hline Mauritania & 1540 & 7.33954 & & 0 & 53.5 & 92.3 & 5.63479 \\
\hline Mauritius & 13210 & 9.48873 & & 0 & 71.38 & 15.5 & 3.41773 \\
\hline Mexico & 6400 & 8.76405 & 7.51 & 0.00013 & 72.18 & 31 & 4.26268 \\
\hline Moldova & 1600 & 7.37776 & & 0 & 67.52 & 28.6 & \\
\hline Mongolia & 1950 & 7.57558 & 7.76 & 0 & 65.85 & 51 & \\
\hline Morocco & 3340 & 8.11373 & 7.09 & 0 & 66.64 & 51 & 4.35927 \\
\hline Mozambique & 810 & 6.69703 & 6.49 & 1 & 45.23 & 114 & \\
\hline Myanmar & 1050 & 6.95655 & 5.9 & 0.49608 & 60.13 & 78.9 & 3.54385 \\
\hline Namibia & 4150 & 8.33086 & 5.4 & 0.24 & 52.41 & 65.3 & \\
\hline Nepal & 1170 & 7.06476 & & 0.04698 & 57.32 & 82.6 & \\
\hline Netherlands & 19950 & 9.90098 & 10 & 0 & 77.92 & 5.8 & \\
\hline New Zealand & 16360 & 9.70259 & 9.74 & 0 & 76.9 & 6.8 & 2.14593 \\
\hline Nicaragua & 2000 & 7.6009 & 5.16 & 0.044 & 67.86 & 43.4 & 5.09559 \\
\hline Niger & 750 & 6.62007 & 5.1 & 0.66 & 48.5 & 115 & 5.99146 \\
\hline Nigeria & 1220 & 7.10661 & 5.49 & 1 & 50.08 & 81.1 & 7.6029 \\
\hline Norway & 21940 & 9.99607 & 9.9 & 0 & 78.14 & 4.9 & \\
\hline Oman & 8140 & 9.00455 & 7.14 & 0.58652 & 70.86 & 25.2 & \\
\hline Pakistan & 2230 & 7.70976 & 6.06 & 0.52671 & 63.95 & 74.1 & 3.61065 \\
\hline Panama & 5980 & 8.69618 & 5.93 & 0.138 & 73.6 & 21.4 & 5.09559 \\
\hline Papua New Guinea & 2420 & 7.79152 & 7.32 & 0.79 & 57.88 & 61.4 & \\
\hline Paraguay & 3650 & 8.20248 & 6.92 & 0.0051 & 69.61 & 39.2 & 4.35799 \\
\hline Peru & 3770 & 8.23483 & 5.94 & 0.00205 & 68.32 & 45 & 4.26268 \\
\hline Philippines & 2850 & 7.95507 & 5.46 & 0.617 & 68.3 & 35.5 & \\
\hline Poland & 5400 & 8.59415 & 7.67 & 0 & 72.52 & 15.2 & \\
\hline
\end{tabular}

\begin{tabular}{|c|c|c|c|c|c|c|}
\hline \multirow{2}{*}{25.8} & 0.964331 & 0.325556 & 1.032291 & & & 2 \\
\hline & 0 & 0.455556 & -6.90776 & & & 3 \\
\hline \multirow[t]{2}{*}{25.41333} & 0.076604 & 0.2 & -6.90776 & & 1 & 2 \\
\hline & 0.487939 & 0.633333 & -6.90776 & & & 3 \\
\hline \multirow[t]{2}{*}{17.76164} & 1 & 0.372222 & -6.90776 & & 1 & 2 \\
\hline & 0 & 0.325556 & -6.90776 & & 0 & 2 \\
\hline 26 & 0.543626 & 0.07 & -6.90776 & & 1 & 0 \\
\hline \multirow[t]{3}{*}{21.3} & 0.105479 & 0.277778 & -0.53541 & & 0 & 2 \\
\hline & 0.165817 & 0.622222 & -5.60164 & & & 3 \\
\hline & 0.1214 & 0.461111 & -6.90776 & & & 3 \\
\hline 23.3 & 0.570964 & 0.222222 & -6.90776 & 536.04 & 0 & 2 \\
\hline 22 & 0 & 0.147778 & -6.90776 & & 0 & 2 \\
\hline 26.7 & 0.794407 & 0.025556 & -2.08636 & 17.7 & 1 & 2 \\
\hline 29.3 & 0 & 0.188889 & -6.90776 & 2940 & 0 & 2 \\
\hline 25.3 & 0.056851 & 0.222222 & -6.90776 & 280 & 0 & 2 \\
\hline 23.5 & 1 & 0.224111 & -6.90776 & 30.5 & 0 & 2 \\
\hline \multirow[t]{2}{*}{19} & 0.37255 & 0.255556 & -2.58961 & 71 & 0 & 0 \\
\hline & 0.073756 & 0.522222 & -6.90776 & & & 3 \\
\hline 0.3 & 0 & 0.511111 & -6.90776 & & 0 & 1 \\
\hline 18.5 & 0.367858 & 0.355556 & -6.90776 & 78.2 & 0 & 2 \\
\hline 23.6 & 0.289927 & 0.201667 & -6.90776 & & 1 & 2 \\
\hline 26.54428 & 0.260857 & 0.244444 & -6.90776 & 34.6 & 1 & 2 \\
\hline 20.1 & 0.165275 & 0.244444 & -6.90776 & & 1 & 3 \\
\hline 18.63333 & 0 & 0.311111 & -6.90776 & & 0 & 0 \\
\hline 8.6 & 0.856014 & 0.581111 & -1.69959 & & 0 & 0 \\
\hline 12.8 & 0.959488 & 0.455556 & -2.73535 & 8.55 & 0 & 0 \\
\hline 26.63333 & 0.632686 & 0.144445 & -6.90776 & 163.3 & 1 & 0 \\
\hline 28.4 & 0 & 0.177778 & -6.90776 & 400 & 0 & 2 \\
\hline 26.65065 & 0.097769 & 0.111111 & -3.19001 & 2004 & 1 & 2 \\
\hline 3.2 & 0.476848 & 0.688889 & 0.458156 & & 0 & 0 \\
\hline 26.9 & 0.479444 & 0.233333 & -0.10749 & & & 0 \\
\hline 23.5 & 0.094196 & 0.333333 & -5.02943 & 36.99 & 1 & 2 \\
\hline 27.5 & 1 & 0.1 & -6.90776 & 163.3 & 1 & 0 \\
\hline 27 & 0.698212 & 0.066667 & -3.04724 & & 0 & 2 \\
\hline 23 & 0 & 0.255556 & -6.90776 & 78.1 & 0 & 0 \\
\hline 20.5 & 0.173208 & 0.111111 & -4.26764 & 71 & 1 & 0 \\
\hline 26.5 & 0.99858 & 0.144445 & -6.77167 & & 1 & 2 \\
\hline 6.4 & 0.165824 & 0.577778 & -5.32163 & & 0 & 1 \\
\hline
\end{tabular}




\begin{tabular}{|c|c|c|c|c|c|c|c|}
\hline Portugal & 12670 & 9.44699 & 9.14 & 0 & 75.29 & 8.9 & \\
\hline Romania & 4360 & 8.38023 & 7.28 & 0 & 69.95 & 22.6 & \\
\hline Russia & 4480 & 8.40738 & & 0 & 66.56 & 17.9 & \\
\hline Rwanda & 540 & 6.29157 & & 1 & 40.5 & 124 & 5.63479 \\
\hline Saudi Arabia & 9910 & 9.2013 & 7.6 & 0.02862 & 71.42 & 23.1 & \\
\hline Senegal & 1780 & 7.48437 & 6 & 1 & 52.32 & 63.2 & 5.10388 \\
\hline Sierra Leone & 580 & 6.36303 & 5.84 & 1 & 37.24 & 170 & 6.18002 \\
\hline Singapore & 22770 & 10.0332 & 9.32 & 0 & 77.1 & 4.9 & 2.87356 \\
\hline Slovakia & 2610 & 7.86711 & 9 & 0 & 72.95 & 11 & \\
\hline Slovenia & 11350 & 9.33697 & & 0 & 74.45 & 6.5 & \\
\hline Somalia & 500 & 6.21461 & 3 & 1 & 46.98 & 122 & \\
\hline South Africa & 5030 & 8.52318 & 6.96 & 0 & 54.73 & 59.2 & 2.74084 \\
\hline Spain & 14520 & 9.58328 & 9.62 & 0 & 78 & 6.6 & \\
\hline Sri Lanka & 3250 & 8.08641 & 6.07 & 0.2 & 73.11 & 17.6 & 4.24563 \\
\hline Sudan & 800 & 6.68461 & 4.01 & 0.81 & 54.97 & 70.9 & 4.47961 \\
\hline Sweden & 18540 & 9.82769 & 9.52 & 0 & 78.55 & 5.4 & \\
\hline Switzerland & 25860 & 10.1605 & 10 & 0 & 78.65 & 5.7 & \\
\hline Syria & 5320 & 8.57923 & 5.8 & 0.0616 & 68.89 & 33 & \\
\hline Taiwan & 13900 & 9.53964 & 9.23 & 0 & & & \\
\hline Tajikistan & 920 & 6.82437 & & 0 & 67.18 & 56.5 & \\
\hline Tanzania & 640 & 6.46147 & 6.75 & 1 & 47.92 & 81.5 & 4.97673 \\
\hline Thailand & 7540 & 8.92798 & 7.61 & 0.47064 & 68.81 & 28.7 & \\
\hline Togo & 1130 & 7.02997 & 6.84 & 1 & 48.84 & 83.9 & 6.50429 \\
\hline Trinidad \& Tobago & 8610 & 9.06068 & 7.42 & 0 & 73.8 & 14.5 & 4.44265 \\
\hline Tunisia & 5000 & 8.51719 & 6.45 & 0 & 69.5 & 30.3 & 4.14313 \\
\hline Turkey & 5580 & 8.62694 & 7.46 & 0 & 69.02 & 45.4 & \\
\hline Turkmenistan & 2080 & 7.64012 & & 0 & 65.36 & 54.8 & \\
\hline Uganda & 1470 & 7.29302 & 4.46 & 1 & 39.64 & 107 & 5.63479 \\
\hline Ukraine & 2400 & 7.78322 & & 0 & 68.77 & 19.1 & \\
\hline United Arab Emirates & 16470 & 9.7093 & 7.16 & 0 & 74.85 & 16 & \\
\hline United Kingdom & 19260 & 9.86579 & 9.79 & 0 & 77.18 & 7 & 2.72785 \\
\hline United States & 26980 & 10.2029 & 10 & 0 & 76.7 & 7.1 & 2.70805 \\
\hline Uruguay & 6630 & 8.79936 & 7.07 & 0 & 73.93 & 17.5 & 4.26268 \\
\hline Uzbekistan & 2370 & 7.77065 & & 0 & 67.52 & 44.3 & \\
\hline Venezuela & 7900 & 8.97462 & 7.1 & 0.0704 & 72.41 & 20.9 & 4.35799 \\
\hline Vietnam & 1450 & 7.27932 & 6.57 & 0.74 & 67.39 & 38.2 & 4.94164 \\
\hline Yemen & 800 & 6.68461 & 6.31 & 0.67308 & 57.99 & 80.2 & \\
\hline Yugoslavia & 2000 & 7.6009 & 6.36 & 0 & 72.82 & 18 & \\
\hline
\end{tabular}

\begin{tabular}{|c|c|c|c|c|c|c|}
\hline 16 & 0.608462 & 0.436667 & -6.90776 & & 0 & 0 \\
\hline \multirow[t]{3}{*}{8.4} & 0.065039 & 0.511111 & -3.12935 & & 1 & 0 \\
\hline & 0.014341 & 0.666667 & -1.46665 & & & 0 \\
\hline & 0 & 0.022222 & -6.90776 & 280 & 1 & 2 \\
\hline 23.7 & 0.124272 & 0.277778 & 0.011003 & & & 1 \\
\hline 27.2 & 0.244762 & 0.155556 & -6.90776 & 164.66 & 0 & 2 \\
\hline 26.2 & 0.466186 & 0.092222 & -6.90776 & 483 & 0 & 2 \\
\hline \multirow[t]{3}{*}{27.1} & 1 & 0.013556 & -6.90776 & 17.7 & 0 & 2 \\
\hline & 0 & 0.537778 & -5.85604 & & & 3 \\
\hline & 0.593033 & 0.511111 & -6.90776 & & & 3 \\
\hline 27.23636 & 0.447487 & 0.111111 & -6.90776 & & 1 & 2 \\
\hline 17.7 & 0.19633 & 0.322222 & -5.91877 & 15.5 & 1 & 0 \\
\hline 15.9 & 0.410256 & 0.444444 & -6.08554 & & 0 & 0 \\
\hline 27.6 & 0.99362 & 0.077778 & -6.90776 & 69.8 & 1 & 2 \\
\hline 28.5 & 0.02323 & 0.166667 & -6.90776 & 88.2 & 1 & 2 \\
\hline 2.4 & 0.301546 & 0.688889 & -6.90776 & & 0 & 0 \\
\hline 5.9 & 0 & 0.522222 & -6.90776 & & 0 & 0 \\
\hline 18.4 & 0.12922 & 0.388889 & -2.30762 & & 1 & 2 \\
\hline \multirow[t]{2}{*}{23.3} & 1 & 0.258889 & -6.02858 & & 0 & 2 \\
\hline & 0 & 0.433333 & -6.90776 & & & 3 \\
\hline 25.09024 & 0.088189 & 0.066667 & -6.90776 & 145 & 0 & 2 \\
\hline 27.2 & 0.272574 & 0.166667 & -4.66565 & & 0 & 0 \\
\hline 26.8 & 0.16769 & 0.088889 & -6.90776 & 668 & 0 & 2 \\
\hline 25.9 & 1 & 0.122222 & -0.81218 & 85 & 0 & 2 \\
\hline 19.6 & 0.479655 & 0.377778 & -3.8103 & 63 & 0 & 2 \\
\hline \multirow[t]{2}{*}{13.2} & 0.383819 & 0.433333 & -5.62115 & & 1 & 1 \\
\hline & 0 & 0.444444 & -1.24003 & & & 3 \\
\hline \multirow[t]{2}{*}{21.57432} & 0 & 0.011111 & -6.90776 & 280 & 1 & 2 \\
\hline & 0.183692 & 0.544444 & -4.12702 & & & 3 \\
\hline 26.19667 & 0.75842 & 0.266667 & 0.871814 & & & 2 \\
\hline 8.8 & 0.923436 & 0.6 & -1.97421 & 15.3 & 0 & 0 \\
\hline 11.2 & 0.111732 & 0.422222 & -2.06846 & 15 & 0 & 0 \\
\hline \multirow[t]{2}{*}{18.4} & 0.312329 & 0.366667 & -6.90776 & 71 & 0 & 0 \\
\hline & 0 & 0.455556 & -2.43596 & & & 3 \\
\hline 24.8 & 0.244409 & 0.088889 & -1.09612 & 78.1 & 0 & 0 \\
\hline \multirow[t]{3}{*}{25.55714} & 0.570282 & 0.177778 & -5.0237 & 140 & 1 & 2 \\
\hline & 0.38457 & 0.166667 & -3.03354 & & 1 & 3 \\
\hline & 0.104 & 0.488889 & -5.1579 & & 0 & 1 \\
\hline
\end{tabular}


Zambia

Zimbabwe

$930 \quad 6.83518$

7.61579

6.68

6.18

$\begin{array}{rrr}1 & 40.09 & 82.1 \\ 0.7 & 44.13 & 68.9\end{array}$

82.1
68.9

2030

44.13
21.3

19.6

$0 \quad 0.166667$

o 0.222222

$-6.90776$

$-6.90776$ 


\section{REFERENCES}

Acemoglu, Daron, Simon Johnson and James A. Robinson (2000). "The Colonial Origins of Comparative Development: An Empirical Investigation," NBER Working Paper \# 7771.

Bloom, David and Jeffrey D. Sachs (1998). "Geography, Demography, and Economic Growth in Africa," Brookings Papers on Economic Activity, 1998:2.

Central Intelligence Agency (CIA) (1996). The World Factbook. Washington, DC: Central Intelligence Agency.

Curtin, Philip D (1989). Death by Migration: Europe's Encounter with the Tropical World in the Nineteenth Century. New York, NY: Cambridge University Press.

-------. (1998). Disease and Empire: The Health of European Troops in the Conquest of Africa. New York, NY: Cambridge University Press.

Easterly, William and Ross Levine (1997). "Africa's Growth Tragedy: Policies and Ethnic Divisions," Quarterly Journal of Economics, CXII, 1213-1250. Data set taken from http://www.worldbank.org/research/growth/ddeale.htm.

Engerman, Stanley and Kenneth Sokoloff (1997). "Factor Endowments, Institutions and Differential Paths of Growth among the New World Economies," in Stephen Haber, ed., How Latin America Fell Behind, Stanford: Stanford University Press.

Gallup, John L. and Jeffrey D. Sachs (1998). "The Economic Burden of Malaria," Center for International Development, Harvard University, October.

Gallup, John Luke, Jeffrey D. Sachs and Andrew Mellinger (1999). "Geography and Economic Development," International Regional Science Review 22, 2: 179-232, August (Reprinted from Annual World Bank Conference on Development Economics, 1998 Proceedings)

Hall, Robert E. and Charles I. Jones (1999). "Why Do Some Countries Produce so Much More Output per Worker than Others?," Quarterly Journal of Economics, CXIV, 83-116.

LaPorta, Rafael, Florencio Lopez-de-Silanes, Andrei Shleifer and Robert W. Vishny (1999). "The Quality of Government," Journal of Law, Economics and Organization, 15, 222-279. 
Masters, William A. and Margaret McMillan (2000). "Climate and Scale in Economic Growth," Center for International Development, Harvard University, June.

Masters, William A. and Keith D. Wiebe (2000). "Climate and Agricultural Productivity," Center for International Development, Harvard University, October.

Sachs, Jeffrey D. (2000). “Tropical Underdevelopment," Center for International Development, Harvard University, September.

United Nations (1996). World Population Prospects 1950-2050. Revised. New York: United Nations.

World Bank (1997). 1997 World Development Indicators. Washington, DC: World Bank.

(1999). 1999 World Development Indicators. [CD-ROM] Washington, DC: World Bank.

------ (2000). 2000 World Development Indicators. [CD-ROM] Washington, DC: World Bank. 